Original article

\title{
Mass occurrence of the liverwort Herbertus sendtneri in a glacial lake in the Andes of Colombia
}

\author{
(ㄱ) Robbert Gradstein ${ }^{1, *}$, (1)Alain Vanderpoorten ${ }^{2}$, Guido van Reenen ${ }^{3}$, $\left(\right.$ Antoine Cleef $^{3}$ \\ ${ }^{1}$ Muséum National d'Histoire Naturelle - Sorbonne Universités, Institut de Systématique, Évolution, Biodiversity (ISYEB), Paris, France \\ ${ }^{2}$ Department of Conservation Biology and Evolution, Institute of Botany, University of Liège, Belgium \\ ${ }^{3}$ Institute for Biodiversity and Ecosystem Dynamics, University of Amsterdam, The Netherlands
}

\begin{abstract}
Many bryophytes grow in the Tropics in periodically inundated habitats such as river beds, marshes and waterfalls, but permanently submerged bryophytes are rare and are mainly found in high-altitude lakes. Their identification can be difficult due to modification of morphological traits induced by the aquatic environment. Here we deal with a submerged population of the liverwort genus Herbertus from a glacial lake at $4120 \mathrm{~m}$ the Sierra Nevada del Cocuy, Colombia. The aquatic plants, which stand out by dwarf statue and obtuse leaf tips, had been identified as $H$. oblongifolius, a rare taxon described from Brazil and recently placed in synonymy of the widespread and variable $H$. sendtneri based on morphology. Molecular analysis confirmed that the aquatic plants belong to H. sendtneri. The resemblance of the aquatic plants to small branches of $H$. sendtneri suggests that they might represent a juvenile phenotype. The aquatic plants probably originated from a rock-inhabiting population, which dispersed into the lake by means of vegetative reproduction via caducous branches or became washed into the lake. The dispersal event should have occurred during the last 12.000-21.000 years when the lake was ice-free. (C) 2018. Acad. Colomb. Cienc. Ex. Fis. Nat.
\end{abstract}

Key words: Aquatic bryophytes; Herbertaceae; Neotropics; Molecular phylogeny; Phenotypic plasticity; Sierra Nevada del Cocuy.

\section{Presencia masiva de la hepática Herbertus sendtneri en una laguna glaciar en los Andes de Colombia}

\section{Resumen}

Muchas especies de briófitas tropicales crecen en habitats periódicamente inundados como lechos del río, pantanos y cascadas, pero se presentan pocos briófitas sumergidas permanentamente y están más que todo en lagunas de alta montaña. Su identificación podría ser dificil por la modificación de rasgos inducidos por el medio acuático.

Aquí se trata de una población sumergida del género Herbertus de las hepáticas de una laguna glaciar a $4120 \mathrm{~m}$ en la Sierra Nevada del Cocuy, Colombia. Las plantas acuáticas caracterizadas por el porte enano y los apices obtusos de las hojas. Se ha identificado como H. oblongifolius, un taxon raro descrito de Brazil y recientemente, basado en la morfología, ubicada como sinónima de la especie variable, H. sendtneri, de distribución amplia.

Análisis molecular ha confirmado que las plantas acuáticas pertenecen a $H$. sendtneri. La semejanza de las plantas acuáticas con las ramitas de $H$. sendtneri parece de sugerir un fenótipo juveníl. Las plantas acuáticas probablemente tienen su origen en una población en las rocas y lajas cercanas y han llegado a la laguna a través de ramitas vegetativas caedizas y así traidas a la laguna por el viento y el agua, o plantas enteras entraron a la laguna con lluvias fuertes inundando las lajas. (C) 2018. Acad. Colomb. Cienc. Ex. Fis. Nat.

Palabras clave: Briofitas acuáticas; Herbertaceae, Neotrópico; Filogénia molecular; Plasticidad fenotípica; Sierra Nevada del Cocuy.

\section{Introduction}

Many bryophytes grow in the Tropics in periodically inundated habitats such as river beds, marshes and waterfalls, and are semi-aquatic. Examples of semi-aquatic rheophilous bryophytes from the Old World Tropics were discussed by Shevock, et al. (2017). In the Neotropics, rheophilous bryophytes are numerous and are found in a wide range of families, such as Amblystegiaceae, Andreaeaceae,
Aneuraceae, Balantiopsidaceae, Brachytheciaceae, Cephaloziellaceae, Fissidentaceae, Fossombroniaceae, Hydropogonaceae, Jungermanniaceae, Lejeuneaceae, Leucomiaceae, Lophocoleaceae, Pelliaceae, Pilotrichaceae, Pottiaceae,

\footnotetext{
*Corresponding autor:

Robbert Gradstein, gradstein@mnhn.fr

Received: May 25, 2018

Accepted: July 17, 2018

Editor: Elizabeth Castañeda
} 
Seligeriaceae, Sematophyllaceae, Sphagnaceae, etc. (e.g., Mägdefrau, 1973; Griffin, et al., 1982; Bartlett \& Vitt, 1986; Gradstein \& Váňa, 1999; Reiner-Drehwald, 1999; Gradstein, et al., 2001, 2004, 2011; Gradstein \& ReinerDrehwald, 2007; Hedenäs, 2003; Crandall-Stotler \& Gradstein, 2017).

Permanently submerged growing bryophytes are far less common in the Tropics. In tropical America they occur in lakes at high elevations in the Andes, mostly above 3000 m. Examples are the liverworts Isotachis obtusa Steph. (= I. lacustris Herzog; Gradstein, unpubl.), Marchantia plicata Nees \& Mont., Gymnocoleopsis cylindriformis (Mitt.) R.M.Schust., Clasmatocolea vermicularis (Lehm.) Grolle, Jensenia spinosa (Lindenb. \& Gottsche) Grolle, Lophonardia laxifolia (Mont.) L.Söderstr. \& Váňa, Syzygiella sonderi (Gottsche) K.Feldberg et al., Herbertus sendtneri, Riccardia paramorum Meenks (= R. cataractarum Steph.; Gradstein, unpubl.) and Ricciocarpos natans (L.) Corda, and the mosses Blindia gradsteinii J.K.Bartlett \& Vitt, Ditrichum submersum Herzog, Drepanocladus Müll.Hal. spp., Fontinalis bogotensis Hampe, Gradsteinia andicola Ochyra, Philonotis andina (Mitt.) A.Jaeger, Pseudocalliergon (Limpr.) Loeske spp., Scorpidium (Schimp.) Limpr. spp. and Sphagnum L. spp. (Cleef, 1981; Gradstein, et al., 2001; Hedenäs, 2003; Churchill, 2018). Most of these taxa, however, may also grow emerged in moist but not permanently inudated habitats. Blindia gradsteinii, Ditrichum submersum, Fontinalis bogotensis and possibly some Sphagnum species are the only truly aquatic bryophyte species in the Andes that are exclusively known from submerged populations. All of them are mosses; none of the liverworts found in lakes in the Andes grow exclusively submerged. Ditrichum submersum and Fontinalis bogotensis are widespread in the Andes of Colombia but Blindia gradsteinii is a very rare species that is only known from a single locality, a small pond at 4090 $\mathrm{m}$ in the páramo de Sumapaz (Churchill, 2016). The semiaquatic Gradsteinia andicola, the only species in the genus Gradsteinia and endemic to Colombia, is a further rare aquatic moss of the páramo de Sumapaz, found once in a dried-up lake at $3650 \mathrm{~m}$.

In temperate regions, submerged bryophytes have been recorded from depths to over $120 \mathrm{~m}$ in clear water lakes (Ignatov \& Kurbatova, 1990; de Winton \& Beever, 2004). They reach to much greater depths than vascular plants, which occur to maximum depths of ca. $12 \mathrm{~m}$ and are scarce or lacking in arctic and high-alpine lakes (Brönmark \& Hansson, 2017). Apparently, bryophytes are better adapted to lower temperatures and lower light intensities than vascular plants (or are outcompeted at lower depths by vascular plants; de Winton \& Beever, 2004). The scarcity of permanently submerged bryophytes in the Tropics and their restriction to high elevations suggests that their occurrence in the Tropics is constrained by high temperatures. Glime \& Vitt (1984) explained the rarity of aquatic bryophytes in the Tropics by the lack of temperature seasonality. Evidence came from ecophysiological studies on the aquatic moss genus Fontinalis Hedw. whose life cycle is fine-tuned adapted to temperature seasonality. The ecophysiology and life cycle of aquatic tropical bryophytes has not been studied, however (Vanderpoorten \& Goffinet, 2009).

The present paper deals with a permanently submerged growing population of the liverwort genus Herbertus (Herbertaceae) from the Andes of Colombia. Many Herbertus species have a preference for very humid habitats such as dripping wet rock, ledges near waterfalls, etc. (Hill, et al., 1991; Paton, 1999), but permanently submerged growth has not been observed in this genus (e.g., Ignatov $\&$ Kurbatova, 1990; de Winton \& Beever, 2004). The aquatic population occurs in a glacial lake, Laguna El Amarillal, in the Serra Nevada del Cocuy (Figure 1) where it was first discovered in 1977 and identified as H. oblongifolius (Steph.) Gradst. \& Cleef (Gradstein, et al., 1977), a species described from the Serra do Itatiaia, southeastern Brazil. Distinctive characters of this species include its very small stature and obtuse leaf tips. Herbertus oblongifolius was considered a very rare taxon known only from the type and the Colombian population (van Reenen, 1982; Gradstein
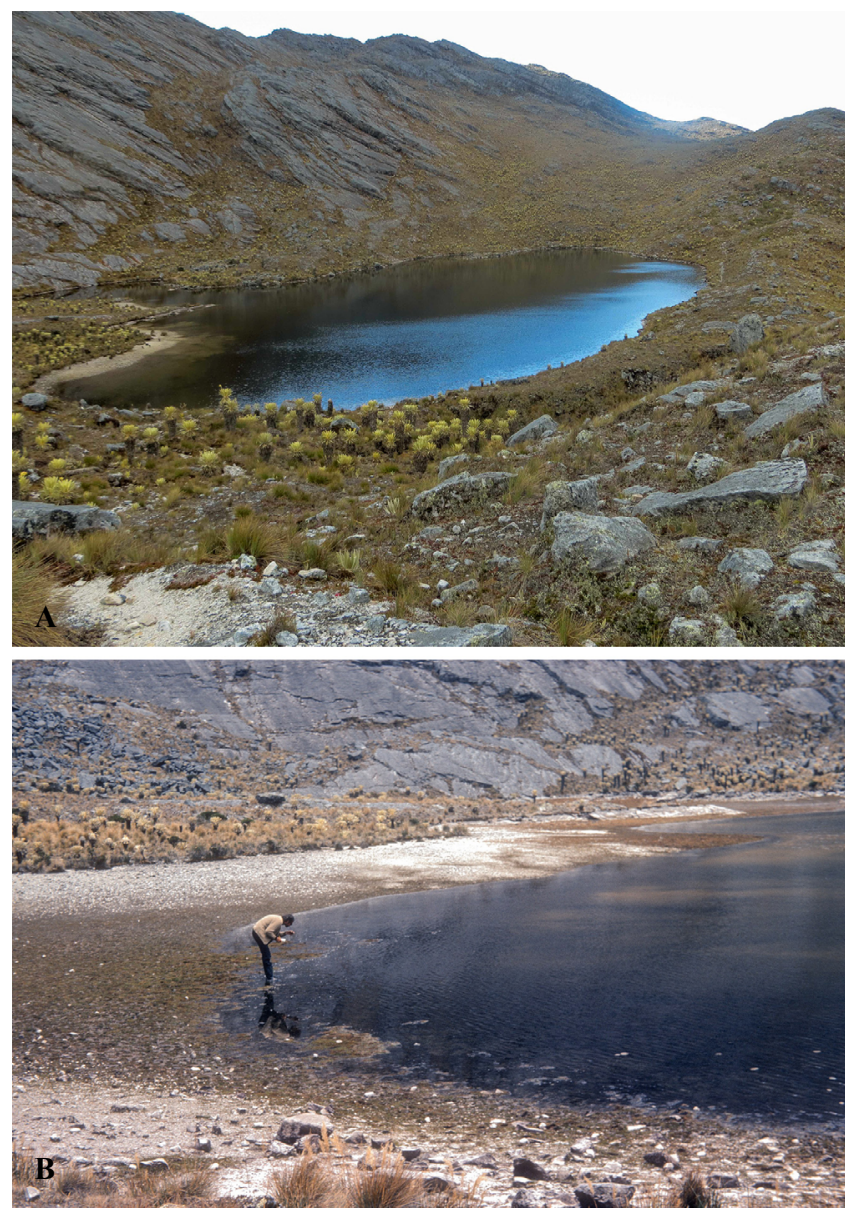

Figure 1. Lake Amarillal in the Sierra Nevada del Cocuy (4120 m), habitat of aquatic $H$. sendtneri 
\& Costa, 2003), but Feldberg \& Heinrichs (2005) treated it as a synonym of the widespread and variable $H$. sendtneri (Nees) Lindb.

Herbertus sendtneri was originally described from the Austrian Alps and had long been considered to be distributed in Central Europe and the Himalayas. Recent molecular and morphological studies, however, indicate that the species is widespread in the Tropics where it had been described under many different names, e.g., H. grossispinus (Steph.) Fulford and $H$. subdentatus auct. in tropical America, and $H$. armitanus (Steph.) H.A.Miller and H. circinnatus (Steph.) H.A.Miller in New Guinea (Feldberg, et al., 2004; He \& Sun, 2017). Herbertus sendtneri grows on rock or bark in humid, high-montane environments, reaching to $4500 \mathrm{~m}$ in the Andes and $5000 \mathrm{~m}$ in the Himalayas. In tropical America the species is found above $2500 \mathrm{~m}$ in Central America and the Andes, from Mexico to Bolivia, and furthermore isolated on Mt. Roraima (Guyana Highlands) and Serra do Itatiaia in southeastern Brazil. Characteristic morphological features of $H$. sendtneri are the frequent presence of ventral-intercalary branches, the falcate-secund to circinnate leaves which are $1.5-3(-4) \times$ longer than wide, the leaf bases with coarse lacinia terminating in a slime papilla, the convex vitta bifurcating at 1/3-3/4 up the leaf lamina and ending well before the apex, and the leaf tips ending in a uniseriate row of 2-25 quadrate to narrowly rectangular cells (Feldberg, et al., 2004; He \& Sun, 2017; Figure 2). The tropical populations tend to be more robust than the European ones, with larger and more elongate leaves and longer leaf tips, but intermediate forms exist and considerable morphological variation is seen.

Herbertus oblongifolius strikingly differs from neotropical $H$. sendtneri in its minute size and obtuse leaf tips (Figure 3). Nevertheless, Feldberg \& Heinrichs (2005) considered $H$. oblongifolius to be a synonym of $H$. sendtneri because of its apparent resemblance to small European phenotypes of the latter species. The putative relationship between $H$. oblongifolius and $H$. sendtneri was not tested with molecular methods, however, and the aquatic population was not cited in Feldberg \& Heinrichs (2005). Since identification of submerged bryophytes can be difficult due to their plastic morphology (de Winton $\&$ Beever, 2004: Rankin, et al., 2017), molecular techniques may help clarifying the taxonomic status of these taxa.

In February 2017 one of us (GR) collected fresh material of the aquatic Herbertus population from Laguna El Amarillal. Here we analyse the relationship between the aquatic plants and $H$. sendtneri based on nuclear DNA sequences and morphology. The aberrant morphology and the origin of the aquatic population are briefly discussed.

\section{Material and methods}

Study area. Laguna El Amarillal is a small and shallow glacial lake in the southernmost area of the Sierra Nevada del Cocuy, Dept. Boyacá, Colombia (Figure 1A). The lake is located at an elevation of $4120 \mathrm{~m}$ on the eastern ridge

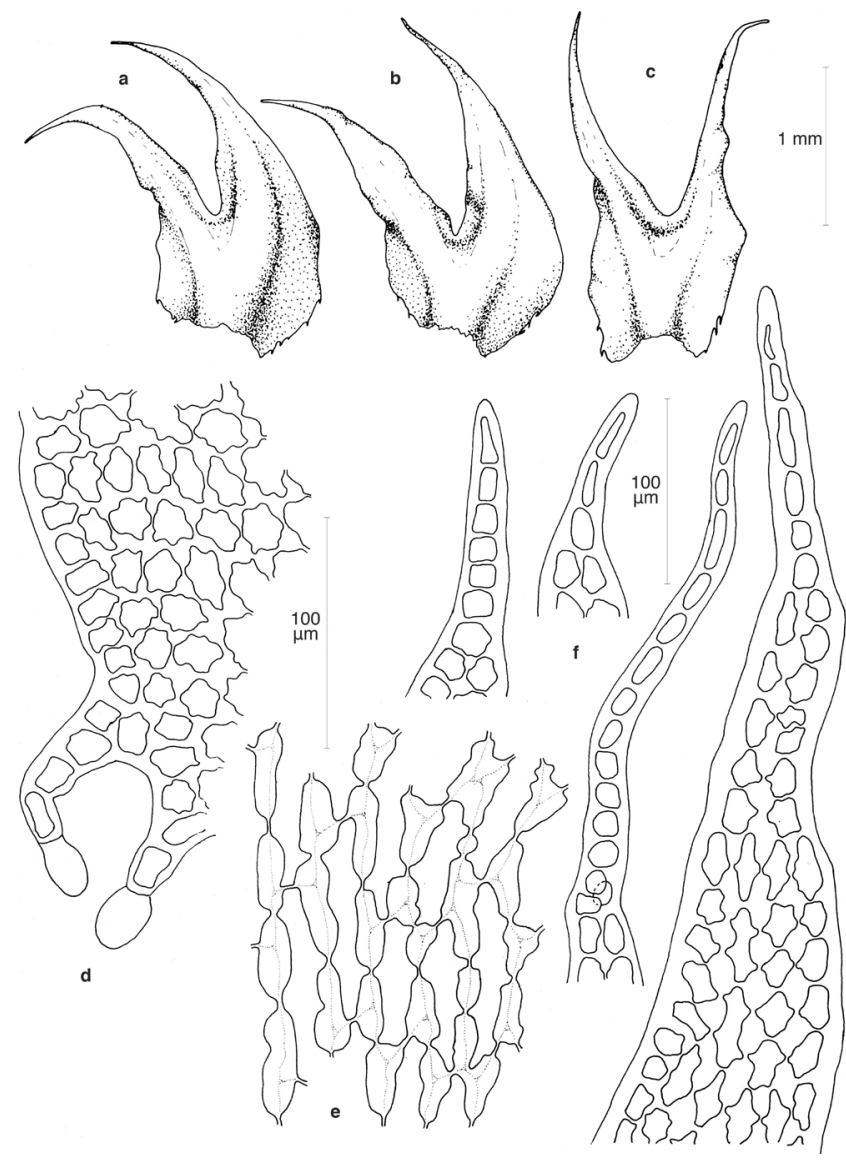

Figure 2. Herbertus sendtneri (after van Reenen, 1982, as $H$. subdentatus)

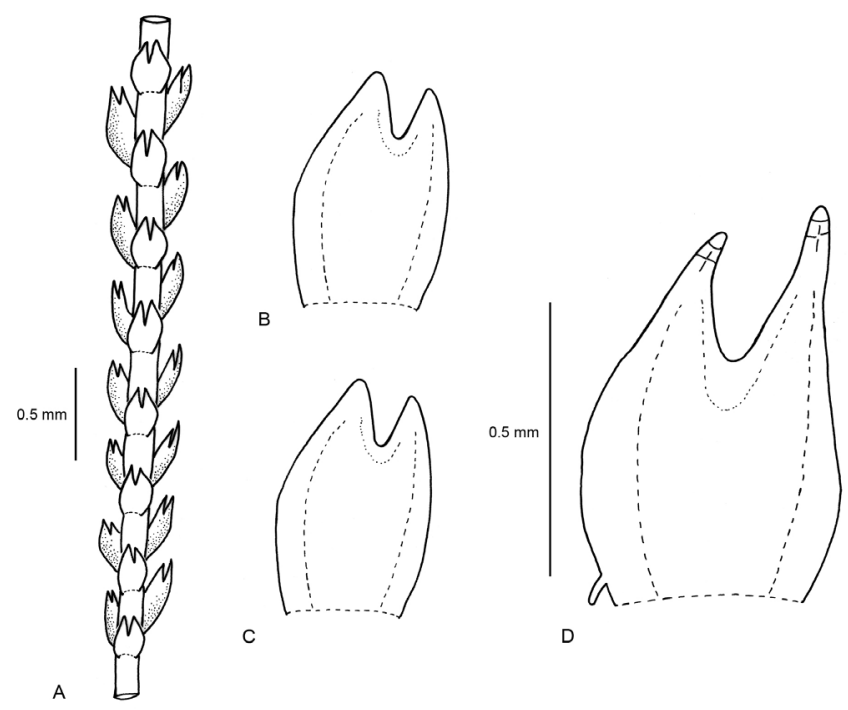

Figure 3. Aquatic Herbertus sendtneri. A. Habit. B. Leaves

of the El Amarillal valley, $6.31620 \mathrm{~N}, 72.32010 \mathrm{~W}$, in an upper grassland páramo dominated by Calamagrostis effusa (Kunth) Steud. with abundant occurrence of Cortaderia cf. 
hapalotricha (Pilg.) Conert (Cleef, 1981). Rock outcrops are covered by Diplostephium colombianum scrub while patches of Chusquea tessellata Munro bamboo vegetation together with stem rosettes of Espeletia lopezii Cuatrec. occur in humid depressions. Espeletia lopezii stands are also seen on flat rocky slopes, associated with extensive mats of the moss Rhacocarpus purpurascens (Brid.) Paris. According to van der Hammen, et al. (1981), the lake area has been ice-free since ca. 12.400-21.000 BP.

Laguna El Amarillal reaches a maximum depth of ca. $2 \mathrm{~m}$ near the South shore, where the lake abruptly ends at a ca. one $\mathrm{m}$ high rock wall. Shallower waters and a narrow sandy beach occur along the northern shore (Figure 1B). The water is clear and the lake bottom consists of a silty sediment with scattered stones. A small vegetation plot of $4 \mathrm{~m} 2$ (Cleef plot nr. 477) sampled in 1977, in $25 \mathrm{~cm}$ deep water near the North shore of the lake, revealed a mass presence of submerged Isoetes karstenii A.Braun (cover 75\%) and Herbertus obtusifolius (cover 35\%). The Herbertus plants were growing anchored in the sediment and the lower stem portions were partially covered by silt and algae. Two further bryophyte species, Ditrichum cf. submersum (cover 3\%) and Isotachis serrulata (cover $<1 \%$ ), were present in small amounts (see also Gradstein, et al., 1977). Towards deeper sites in the lake the cover of submerged $H$. obtusifolius increased to $75-80 \%$. The mass presence of the latter species in deeper parts of the lake was reflected by a reddish-brown hue. In the sample of $H$. obtusifolius taken in 2017, the species was accompanied by Ditrichum sp., Campylopus densicoma (Müll.Hal.) Paris var. yungarum (Herz.) Frahm, Bryum sp. (etiolated plants with long, branched protonemal filaments sprouting from leaf axils) and Syzygiella sonderi. The $\mathrm{pH}$ of the lake water was not determined but is probably similar to that of the uppermost soil layer of the surrounding bunchgrass páramo, measuring between 5.0 and 5.5 (Cleef, 1981).

Molecular approach. DNA of aquatic H. oblongifolius (van Reenen 5795, COL, PC) was extracted, amplified and sequenced at the nrITS locus previously used in specieslevel phylogenetic analyses of the genus following the protocols of Feldberg, et al. (2004) and Feldberg \& Heinrichs (2006). In an attempt to confirm the nested position of $H$. oblongifolius within the $H$. sendtneri complex, we first downloaded from GenBank ITS sequences for one individual per Herbertus species (Table 1). We then focused on the $H$. sendtneri complex, sampling each of the available sequences of the complex. Each dataset was submitted to a Maximum Likelihood analysis with Seaview 4.6.4 (Gouy, et al., 2010). Each analysis implemented a GTR substitution model with a gamma distribution to take among-site variation into account according to the results of a model selection employing the AIC criterion with Jmodeltest (Darriba, et al., 2012).

Morphological approach. We studied the type of H. obtusifolius and fresh material of the aquatic plants from Colombia as well as selected herbarium material of Herbertus sendtneri from Colombia, Brazil and Central Europe. All specimens were examined by light microscopy. The following specimens were studied: Herbertus obtusifolius. Colombia. Boyacá, Sierra Nevada del Cocuy, Laguna El Amarillal, March 1977, Cleef \& van der Hammen 10382 (COL, G, U), ibid., van Reenen 5795 (COL, PC). BrazIL. Rio de Janeiro: Parque National Itatiaia, Agulhas Negras, 2400 m, Ule 448, holotype of Schisma oblongifolia Steph. (G-00052085 [= G-18848]). Herbertus sendtneri. Colombia. Arauca: Sierra Nevada del Cocuy, Quebrada El Playón, Hoya S. Luis, 3540 m, large form, Cleef 9129 (PC, U), ibid, small form, Cleef 9137 (PC, U); Quebrada El Playón, Patio Bolos, 4260 m, large form, Cleef 9095 (PC, U). Boyacá: Sierra Nevada del Cocuy, Boquerón de Cusirí, small form, Cleef 8811 (PC, U), ibid., paso del Conejo, 4450 $\mathrm{m}$, small form, Cleef $8713 \mathrm{~b}$ (PC), ibid. Quebrada Bocatoma, large form, Florschütz 4050a (PC, U), ibid., above laguna Pintada, 4300-4700 m, small form, Bischler 2831, 2846 (PC), ibid., Las Playitas, $3950 \mathrm{~m}$, Bischler 2803 (PC). Cundinamarca: Páramo de Palacio, $3800 \mathrm{~m}$, small form, Cleef 5255 (PC, U); Cerro Nevado del Sumapaz, 3715 m, large form, Cleef $8196 b$ (PC, U), ibid., Andabobos, $3800 \mathrm{~m}$, large form, Cleef 779 (PC, U), ibid., $4300 \mathrm{~m}$, large form, Cleef 1363 (PC, U). BRAZIL. Rio de Janeiro: Parque National Itatiaia, Agulhas Negras, ca. 2500 m, large form, Vital 4896 (PC, U). Austria. Tirol: Kitzbühl, 2000 m, on rock, Sauter s.n., Husnot Hepaticae Galliae 159 (PC); Kuthei, $6500 \mathrm{ft}$., Arnold s.n. (PC).

\section{Results and discussion}

Molecular phylogeny. In the analysis of the whole genus, $H$. oblongifolius was resolved as sister to $H$. sendtneri with 93\% of bootstrap support (Figure 4). Within the H. sendtneri complex, H. oblongifolius is nested within the Neotropical clade, which has a bootstrap support of $78 \%$ (Figure 5). The molecular data show that the aquatic Herbertus population belongs to $H$. sendtneri and support the synonymy of $H$. oblongifolius under $H$. sendtneri as proposed by Feldberg \& Heinrichs (2005) on morphological grounds.

Morphology. The gametophytes of the aquatic plants from Colombia are characterized as follows (Figure 3; notable features italicized): Plants dull greenish-brown to blackish, very slender, flagelliform, 0.4-0.5 $\mathrm{mm}$ wide, to $4 \mathrm{~cm}$ long, unbranched or very sparingly branched with ventralintercalary branches. Rhizoids \pm lacking. Leaves scale-like, 0.3-0.8 mm long, 1.3-2 $\times$ longer than wide, distant to densely imbricate, bifid to $1 / 3-1 / 2$, lobes erect, narrowly triangular, slightly unequal in size, dorsal lobe slightly broader than ventral lobe; leaf lamina oblong-quadrate to obovate, margins almost straight, without appendages or occasionally with 1(-2) short cilia tipped by a slime papilla, lacinia absent; lobe bases not overlapping in the sinus, lobe margins entire, lobe tips obtuse, made up of one blunt hyaline cell (very rarely 2), uniseriate part lacking. Leaf cells with large 
Table 1. Voucher information and GenBank accession numbers of Herbertus specimens used in this study; new sequence in bold

\begin{tabular}{|c|c|c|}
\hline Taxon & Voucher & Accession number \\
\hline H. acanthelius Spruce & Ecuador, Gradstein \& Mandl 10144 (GOET) & AJ783339 \\
\hline H. bivittatus Spruce & Panama, Salazar \& Gradstein $9286(\mathrm{H})$ & DQ293948 \\
\hline H. borealis Crundw. & $\mathrm{UK}$, EDNA09-01443 (E) & JN113499 \\
\hline H. circinatus (Steph.) H.A.Miller & Papua New Guinea, Norris $66970(\mathrm{H})$ & KU523777 \\
\hline H. delavayi (Steph.) Steph. & Bhutan, Long 28864 (GOET) & AJ972450 \\
\hline H. dicranus (Gottsche et al.) Trevis. & Nepal, Long $30554(\mathrm{H})$ & KU523784 \\
\hline H. gracilis (Mont.) Steph. & Hawaii, Weber \& Randolph B89,875 (UC) & DQ293949 \\
\hline H. hutchinsiae (Gottsche \& Rabenh.) A.Evans & British Isles, Rycroft 01015 (GOET) & AJ783340 \\
\hline H. kurzii (Steph.) R.S.Chopra & Bhutan, Long $28864(\mathrm{H})$ & KU523787 \\
\hline H. longifissus Steph. & Papua New Guina, Norris $63194(\mathrm{H})$ & DQ293952 \\
\hline H. norenus D.G.Long et al. & $\mathrm{UK}$, EDNA09-00734 (E) & JN113520 \\
\hline H. oblongifolius (Steph.) Gradst. \& Cleef & Colombia, van Reenen 5795 (PC) & МH379706 \\
\hline H. oldfieldianus (Steph.) Rodway & New Zealand, Glenny $8857(\mathrm{H})$ & KU523778 \\
\hline H. pilifer Schiffn. & Papua New Guinea, Kluiving $1453(\mathrm{H})$ & DQ293955 \\
\hline H. runcinatus (Taylor) Trevis. & St Helena, Gremmen 2000-170 (GOET) & FN582125 \\
\hline H. sakuraii (Warnst.) S.Hatt. & Alaska, Schofield $115671(\mathrm{H})$ & KU523788 \\
\hline H. sendtneri (Lindb.) Lindb. - "Americal" & Bolivia, Heinrichs et al. 4001 (GOET) & AJ783350 \\
\hline H. sendtneri - "America2" & Bolivia, Heinrichs et al. 4004 (GOET) & AJ783352 \\
\hline H. sendtneri - "America3" & Costa Rica, Gradstein \& Mues 9711 (GOET) & AJ783353 \\
\hline H. sendtneri - "America4" (= America8) & Costa Rica, Holz \& Schäfer-V. 0077 (GOET) & AJ783354 \\
\hline H. sendtneri - "America5" & Bolivia, Churchill 22797 (GOET) & AM157352 \\
\hline H. sendtneri - "America6" & Bolivia, Churchill et al. 22797 (GOET) & AM259599, AM157352 \\
\hline H. sendtneri - "America7" & Ecuador, Heinrichs et al. 4418 (GOET) & AM11361 \\
\hline H. sendtneri - "America9" & Bolivia, Heinrichs et al. 4002 (GOET) & AJ783351 \\
\hline H. sendtneri - "America10" & Panama, Dauphin et al. 1576 (GOET) & AJ783355 \\
\hline H. sendtneri - "America11" & Bolivia, Groth s.n. (GOET) & AJ413177 \\
\hline H. sendtneri - "Asial”" & China, Long $24180(\mathrm{H})$ & KU523785 \\
\hline H. sendtneri - “Asia2” & Indonesia, Schäfer-V. 25286 (GOET) & AM259600 \\
\hline H. sendtneri - "Asia3" & Bhutan, EDNA09-01007 (E) & JN113521 \\
\hline H. sendtneri - "Asia4" & China, Long $24180(\mathrm{H})$ & KU523785 \\
\hline H. sendtneri - "Asia 5" & Bhutan, Miehe 00-380-01 (GOET) & AM259598 \\
\hline H. sendtneri - "Asia6" & Indonesia, Schäfer-V. 25004 (GOET) & AM259601 \\
\hline H. sendtneri - “Asia7” & Indonesia, Schäfer-V. 25172 (GOET) & AM259602 \\
\hline H. sendtneri - "Asia8" & Malaysia, Schäfer-V. 18872 (GOET) & AM259604 \\
\hline H. sendtneri - “Asia9” & Indonesia, Gradstein et al. 11011 (GOET) & AM259603 \\
\hline H. sendtneri - "Asia10” & Malaysia, Gradstein 10353 (GOET) & AJ972453 \\
\hline H. sendtneri & Austria, Heinrichs 4377 (GOET) & AJ783347 \\
\hline H. sendtneri & Austria, Heinrichs 4378 (GOET) & AJ783348 \\
\hline H. sendtneri & St Helena, Gremmen 2000-904 (GOET) & FN582126 \\
\hline H. sendtneri & Madeira, $R G 2402(\mathrm{GOET})$ & AJ783349 \\
\hline H. stramineus (Dumort.) Lett. & $\mathrm{UK}$, EDNA09-00735 (E) & JN113528 \\
\hline
\end{tabular}

trigones, cuticle \pm smooth. Vitta occupying 2/3-3/4 the width of the lobe bases, bifurcating just below the sinus (at 3/4$5 / 6$ up the leaf lamina), not extending to the lobe apex. Oil bodies present in all leaf cells, 5-8 in margin cells, 7-14 in vitta cells, globose to bluntly subellipsoid, $5-7 \times 6-10 \mu \mathrm{m}$, colorless, finely and rather faintly granular, becoming almost homogeneous upon age. Underleaves similar to leaves but more symmetrical, the two lobes equal in width. 


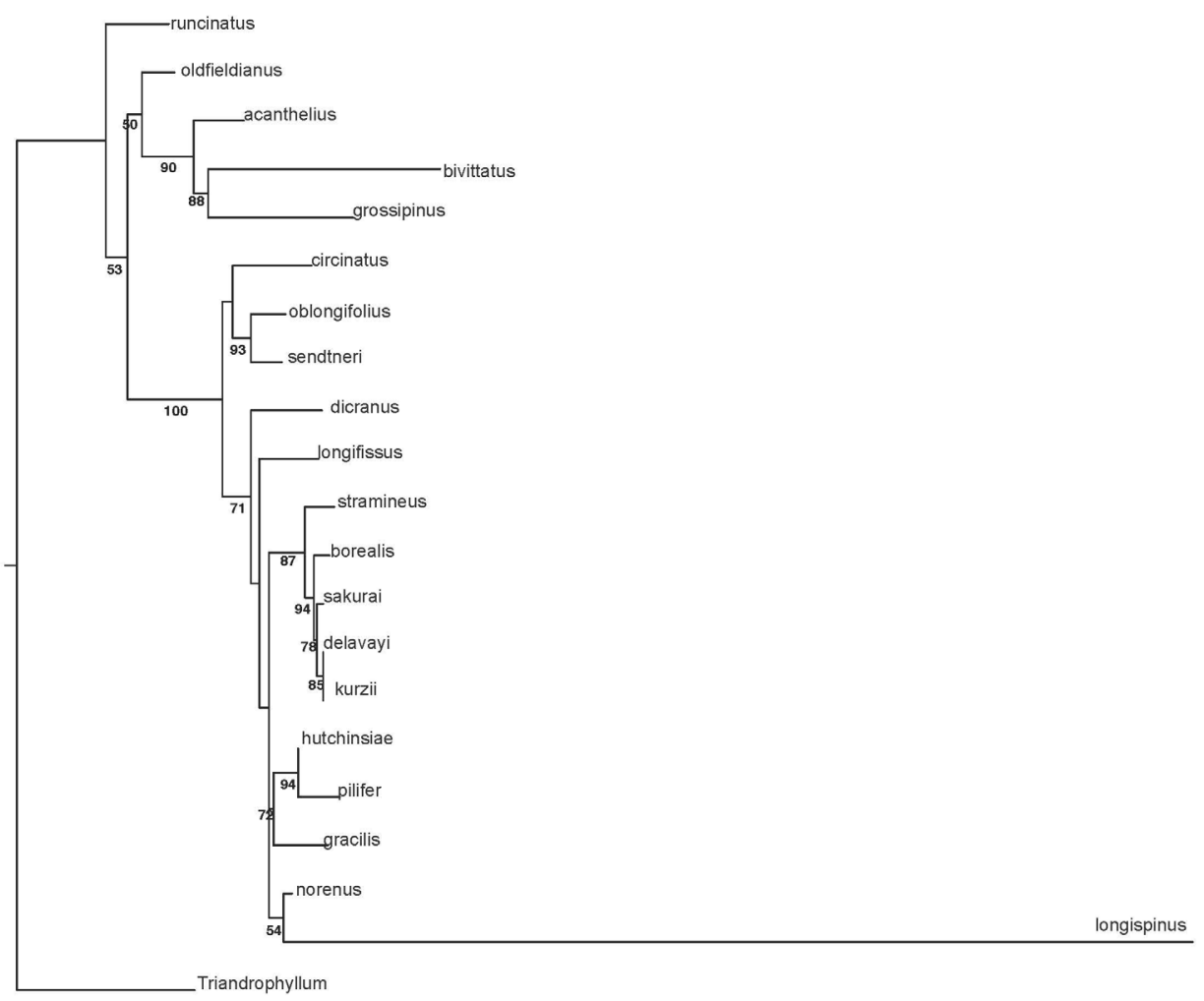

Figure 4. Most likely tree resulting from the analysis of sequence variation at the ITS locus in Herbertus

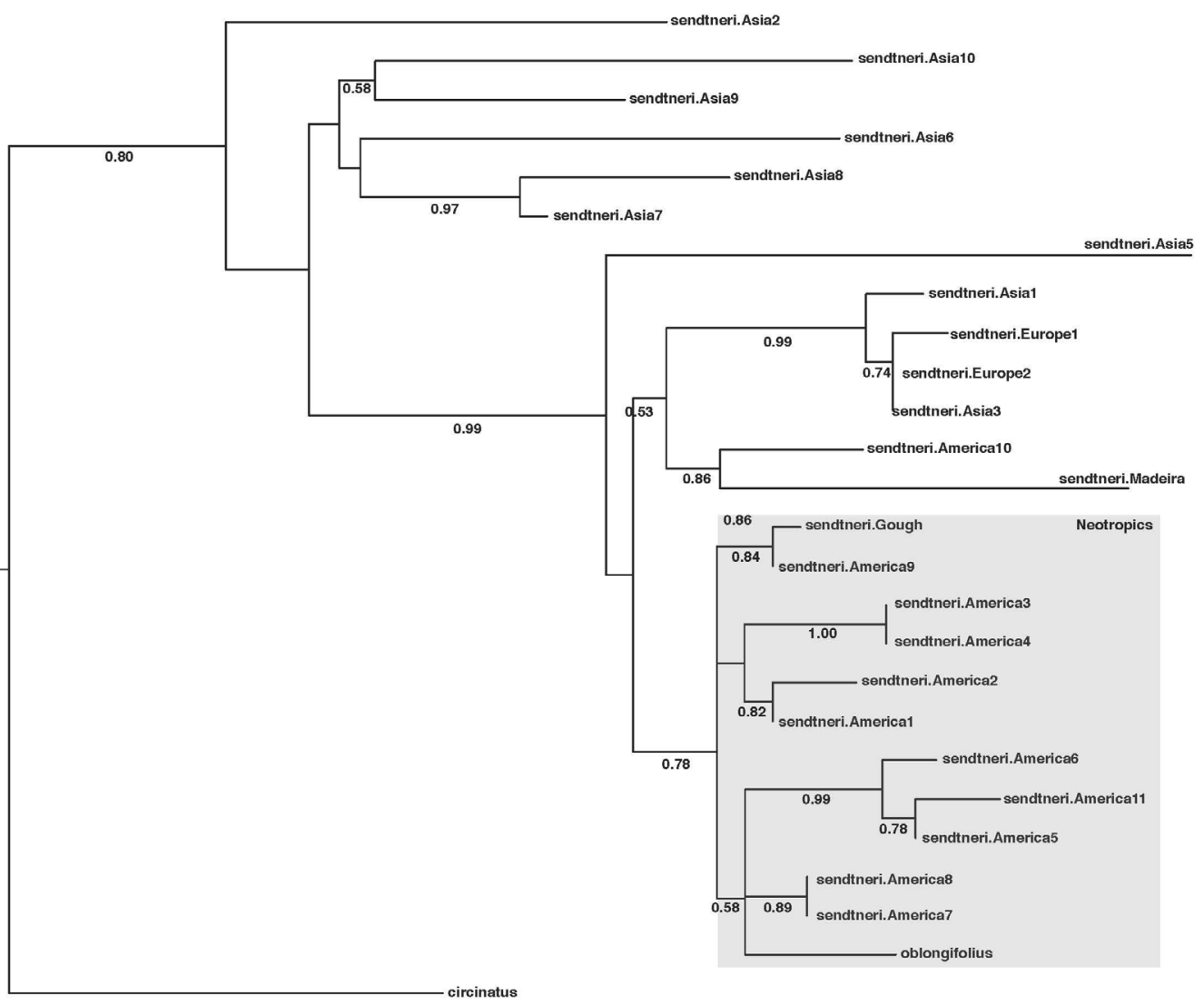

Figure 5. Most likely tree resulting from the analysis of sequence variation at the ITS locus in $H$. sendtneri 
The aquatic plants strikingly differ from typical neotropical $H$. sendtneri by the very slender, almost unbranched shoots, the small, scale-like leaves, the absence of lacinia, the obtuse leaf tips made up of one cell (very rarely 2), and the broad vitta. Examination of selected neotropical specimens of $H$. sendtneri confirmed the presence of major morphological variation in this species as reported by van Reenen (1982, as H. subdentatus auct.) and Feldberg, et al. (2004). Van Reenen (1982) recognized three different phenotypes of $H$. sendtneri in the Colombian Andes: a "circinnate-leaved" form, a "large" form and a "small" form, which are grading into each other (Figure 6). Stem leaves in the large form are 1.5-3 $\mathrm{mm}$ long and distinctly falcato-secund, those in the small form $0.8-1.5 \mathrm{~mm}$ long and less falcate, while those in the circinnate-leaved form are long as in the large form but conspicuously circinnate. The large form was the most common phenotype and occurred on bark, rock or soil between $3200-4100 \mathrm{~m}$. The other two phenotypes had more restricted habitat preferences, the small form occurring on exposed rock (occasionally on soil) in relatively dry or very wet páramo between 3500 $4450 \mathrm{~m}$ while the circinnate-leaved form was restricted to bark in humid cloud forest near the forest line, at 3400$3550 \mathrm{~m}$. The phenotypic variation observed in the Colombian populations is much greater than in European populations, which resemble the small form from Colombia and likewise occur on rock (Meinunger \& Köckinger, 2002). The latter authors reported a tendency among the European populations to become reduced in plant size in relatively dry habitats, with leaves becoming shorter and broader. Plant size reduction in the European populations was not observed in wet habitats, however.

A comparison of the aquatic plants with the phenotypes described by van Reenen (1982) shows greatest resemblance to the small form, especially to small branches of the latter, which are rather similar in width, leaf size and shape, short leaf tips and absence of lacinia at leaf base, even though showing more variation in leaf tip length (Table 2). The similarity of the aquatic plants to branches of the small form suggests that the aquatic plants might represent a juvenile phenotype of $H$. sendtneri. The flagelliform habit, the 1-celled leaf tips and the broad vitta, observed also in the type of $H$. obtusifolius from Serra do Itatiaia, are the most distinctive features of this phenotype. The aberrant morphology of the aquatic $H$. sendtneri plants fits the notion that submerged bryophytes frequently have unusual morphologies (Vitt \& Glime, 1984; Wagner, et al., 2000; de Winter \& Beever, 2004; Rankin, et al., 2017). De Winter

A
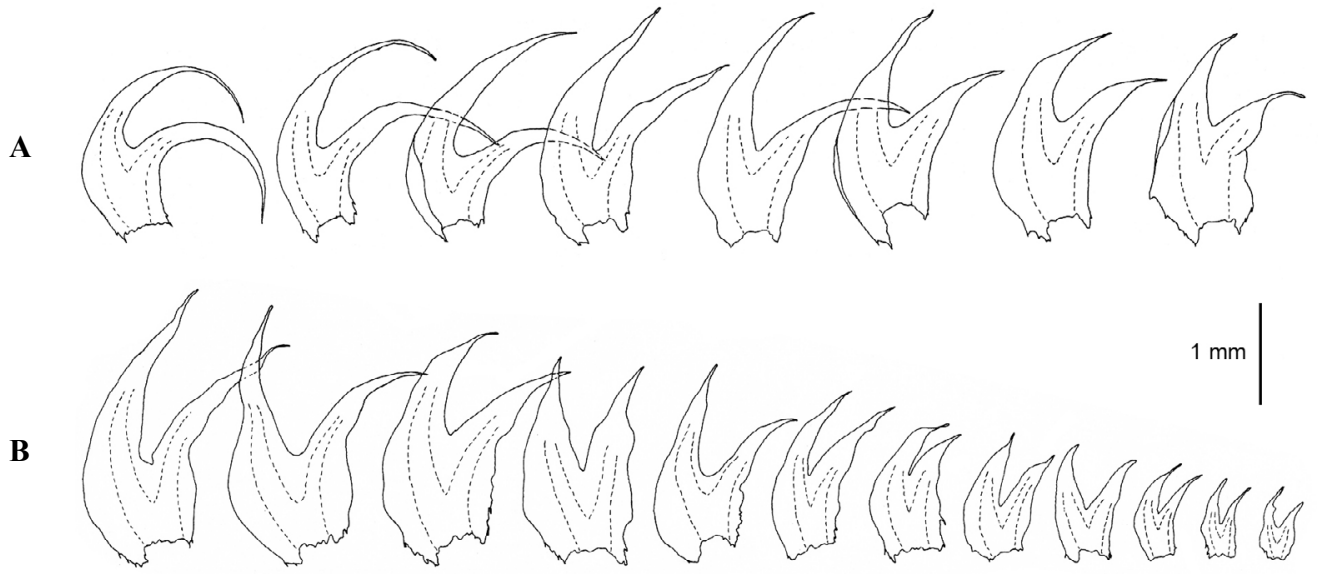

Figure 6. Variation in leaf size and shape in Herbertus sendtneri from Colombia (after van Reenen, 1982, as H. subdentatus): circinnate form (top left), large form (top right, bottom left), small form (bottom right)

Table 2. Comparison of aquatic $H$. sendtneri with the small form of $H$. sendtneri from the Sierra Nevada del Cocuy

\begin{tabular}{lccc}
\hline & \multicolumn{2}{c}{ Small form } & Aquatic (stems) \\
\cline { 2 - 3 } & Stems & Branches & $0.4-0.5 \mathrm{~mm}$ \\
\hline Shoot width & $0.7-1.4 \mathrm{~mm}$ & $0.3-0.6 \mathrm{~mm}$ & $0.3-0.8 \mathrm{~mm}$ \\
Leaf length & $0.8-1.5 \mathrm{~mm}$ & $0.3-0.75 \mathrm{~mm}$ & $1.4-2: 1$ \\
Leaf length : width & $1.7-2: 1$ & $1.4-2: 1$ & $0(-2)$, ciliate \\
Leaf appendages & $0-2$, ciliate or laciniate & $0(-1)$, ciliate & $1(-2)$ cells \\
Leaf tips (uniseriate part) & $3-7$ cells & $1-7$ cells & $3 / 4-5 / 6$ \\
\hline Vitta bifurcation at lamina height & $1 / 3-3 / 4$ & $1 / 3-3 / 4$ & \\
\hline
\end{tabular}


\& Beever (2004) found that bryophytes in deep-water lakes of New Zealand often possessed narrow, sterile shoots with scale-like leaves and reduced branching, and they suggested that these shoots reflected an extended juvenile state of the species. The results of our study fully agree with these observations.

Interestingly, the shoots tips in the aquatic Herbertus material collected in 1977 were frequently swollen and ball-shaped by crowding of leaves, resembling gynoecia. However, no archegonia were found inside these structures; instead, we found small, whitish colonies of unidentified protozoans, resembling gnathifers. We also observed that growth of the infected shoot tips was inhibited and was being continued by innovating branches (1-2) sprouting from below the swollen shoot tips.

Origin of the aquatic plants. We suggest that the aquatic plants may have originated from the small, rock-inhabiting populations of $H$. sendtneri, which are common in the Sierra Nevada del Cocuy (A.M. Cleef, pers. obs.). These plants sometimes produce caducous branches (e.g., Cleef 8811 ), which may have acted as a means of unspecialized vegetative reproduction and may have dispersed into the lake. Alternatively, rain-swollen streams from the rocky slopes ('lajas') could have washed the plants into the lake, or the plants might have established on the shore when the water level was low and became secondarily submerged. Dispersal into the lake must have occurred during the last 12.000-21.000 years, when the lake has been ice-free. The question remains whether the aquatic plants originated from one single dispersal event, resulting in one clonal population, or whether they became established in the lake via multiple dispersal events.

\section{Contributions of the authors}

RG did the morphological study and wrote the article, AV did the molecular analysis, GVR collected the fresh material and contributed illustrations, and AMC and GVR provided data on the habitat and the origin of the aquatic plants. All authors contributed to the text.

\section{Conflict of interest}

The authors declare that they have no conflict of interest.

\section{Acknowledgments}

We express our gratitude to the curators of the herbaria of COL, G, PC and U for making material available for study, to Steven P. Churchill for information on Ditrichum submersum, to Janice Glime for help with literature and to Ludivine Longou (UMS2700, CNRS, MNHN Paris) for preparing part of the figures for publication.

\section{References}

Bartlett, J.K. \& Vitt, D.H. (1986). A survey of the species in the genus Blindia (Bryopsida, Seligeriaceae). New Zealand Journal of Botany, 24: 203-246.
Brönmark, C. \& Hansson, L.A. (2017). The Biology of Lakes and Ponds, 2nd ed. Oxford: Oxford University Press.

Churchill, S.P. (2016). Bryophyta. In: Bernal, R., Gradstein, S.R. \& Celis, M. (eds.). Catálogo de plantas y líquenes de Colombia (pp. 353-442). Bogotá: Universidad Nacional de Colombia.

Churchill, S.P. (2018). Andean Bryophytes. www.tropicos.org/ Project/ANBRY

Cleef, A.M. (1981). The vegetation of the páramos of the Colombian Cordillera Oriental. Dissertationes Botanicae, 61: 1-320.

Crandall-Stotler, B.J. \& Gradstein, S.R. (2017). A new riverine species of the genus Fossombronia (Pelliales, Fossombroniaceae) from Ecuador. Bryophyte Diversity and Evolution, 39: 94-101.

Darriba, D., Taboada, G.L., Doallo, R., Posada, D. (2012). jModelTest 2: more models, new heuristics and parallel computing. Nature Methods, 9: 772.

de Winton, M.D. \& Beever, J.E. (2004). Deep-water bryophyte records from New Zealand lakes. New Zealand Journal of Marine and Freshwater Research, 38: 329-340.

Feldberg, K., Groth, H., Wilson, R., Schäfer-Verwimp, A., Heinrichs, J. (2004). Cryptic speciation in Herbertus (Herbertaceae, Jungermanniopsida): Range and morphology of Herbertus sendtneri inferred from nrITS sequences. Plant Systematics and Evolution, 249: 247-261.

Feldberg, K. \& Heinrichs, J. (2005). Some new synonyms of Herbertus sendtneri (Nees) Lindb. from the Neotropics. Cryptogamie, Bryologie, 26: 411-416.

Feldberg, K. \& Heinrichs, J. (2006). A taxonomic revision of Herbertus in the Neotropics based on nuclear and chloroplast DNA and morphology. Botanical Journal of the Linnean Society, 151: 309-332.

Glime, J. \& Vitt, D.H. (1984). The physiological adaptations of aquatic Musci. Lindbergia, 10: 41-52.

Gouy, M., Guindon, S., Gascuel, O. (2010). SeaView version 4: a multiplatform graphical user interface for sequence alignment and phylogenetic tree building. Molecular Biology and Evolution, 27: 221-224.

Gradstein, S.R. \& Costa, D.P. (2003). The liverworts and hornworts of Brazil. Memoirs of the New York Botanical Garden, 87: 1-317.

Gradstein, S.R. \& Reiner-Drehwald, M.E. (2007). On the status of Neopotamolejeunea E.Reiner (Lejeuneaceae), with description of a new species. Systematic Botany, 32: 487-492.

Gradstein, S.R. \& Váňa, J. (1999). On the taxonomy of Kymatocalyx and Stenorrhipis (Cephaloziellaceae). Haussknechtia Beiheft, 9: 155-170.

Gradstein, S.R., Churchill, S.P., Salazar Allen, N. (2001). Guide to the Bryophytes of Tropical America. Memoirs of the New York Botanical Garden, 86: 1-577.

Gradstein, S.R., Cleef, A.M., Fulford, M.H. (1977). Oil body structure and ecological distribution of selected species of Andean Jungermanniales. Proceedings of the Koninklijke Nederlandse Akademie van Wetenschappen C, 80: 377-420.

Gradstein, S.R., Ilkiu-Borges, A.-L., Vanderpoorten, A. (2011). Habitat specialization triggers the evolution of unusual morphologies: the case of Cololejeunea stotleriana sp. nov. from Ecuador. The Bryologist, 114: 9-22.

Gradstein, S.R., Reiner-Drehwald, M.E., Jost, L. (2004). The systematic position and distribution of Myriocolea irrorata (Lejeuneaceae, Hepaticae), an endangered liverwort from the Ecuadorian Andes. Journal of the Hattori Botanical Laboratory, 93: 235-248. 
Griffin, D., Gradstein, S.R., Aguirre, J. (1982). On a new antipodal element in the Neotropical paramos: Dendrocryphaea latifolia sp. nov. Acta Botanica Neerlandica, 31: 175-184.

He, X.L. \& Sun, Y. (2017). Rare sporophyte found in Europe for Herbertus sendtneri with a range expansion to Africa and Malaysia. Phytotaxa, 324: 42-50.

Hedenäs, L. (2003). Amblystegiaceae. Flora Neotropica Monograph, 89: 1-107.

Hill, M., Preston, C.D., Smith, A.J.E. (1991). Atlas of the Bryophytes of Britain and Ireland. Vol. 1: Liverworts. Colchester: Harley Books.

Ignatov, M. \& Kurbatova, B. (1990). A review of deep-water bryophytes with records from USSR. Hikobia, 10: 393-401.

Mägdefrau, K. (1973). Hydropogon fontinaloides (Hook.) Brid., ein periodisch hydro-aerophytisches Laubmoos des Orinoco und Amazonas. Herzogia, 3: 141-149.

Meinigunger, L. \& Köckinger, H. (2002). Herbertus sendtneri (Nees) Lindb. - neue Einzelheiten zum historischen Fund im Thüringer Wald und Bemerkungen zur Variabilität der Art. Limprichtia, 20: 31-46.

Paton, J.A. (1999). The Liverwort Flora of the British Isles. Colchester: Harley Books.

Rankin, A.H., Pressel, S., Duckett, J., Rimington, W.H., Hawes, I., Sumners, D.Y., Mackey, T.J., Castendyke, D., Schneider, H., Jungblut, A.D. (2017). Characterisation of a deep-water moss from the perennially ice-covered Lake Vanda, Antarctica. Polar Biology. DOI 10.1007/s00300$017-2127-y$

Reiner-Drehwald. E. (1999). On Potamolejeunea polyantha (Mont.) E.Reiner \& Goda comb. nov. (Lejeuneaceae), a poorly known rheophytic liverwort from South America. Haussknechtia Beiheft, 9: 299-306.

Shevock, J., Wen-Shang, M.Z., Akiyama, H. (2017). Diversity of the rheophytic condition in bryophytes: field observations from multiple continents. Bryophyte Diversity and Evolution, 39: 75-93.

van Reenen, G.B.A. (1982). Studies on Colombian Cryptogams XII. High Andean species of Herbertus S. F. Gray (Hepaticae). Lindbergia, 8: 110-120.

van der Hammen, T., Barelds, J., de Jong, H., de Veer, A.A. (1981). Glacial sequence and environmental history in the Sierra Nevada del Cocuy (Colombia). Paleogeography, Paleoclimatology, Paleoecology, 32: 247-340.

Vanderpoorten, A. \& Goffinet, B. (2009). Introduction to Bryophytes. Cambridge: Cambridge University Press.

Wagner, D.H., Christy, J.A., Larson, D.W. (2000). Deep-water bryophytes from Waldo Lake, Oregon. Lake and Reservoir Management, 16: 91-99. 